\title{
Original Paper \\ Flora of Acanthaceae of Iguaçu National Park, Paraná, Brazil
}

\author{
Janaine Kunrath Hammes ${ }^{1,5}$, Marizete Gonçalves da Silva ${ }^{2}$, Cíntia Kameyama ${ }^{3}$ \& Lívia Godinho Temponi ${ }^{4}$
}

\begin{abstract}
Species of Acanthaceae are predominantly associated with conserved forest environments such as Iguaçu National Park (PARNA Iguaçu), which is composed of Semideciduous Seasonal Forest and Araucaria forest. The aim of this work was to perform a floristic study of Acanthaceae of PARNA Iguaçu, with botanical illustrations, an identification key and descriptions of the species. Collections were carried out monthly from August 2015 to July 2016, in the areas of Céu Azul, Capanema and Foz do Iguaçu. The individuals collected were deposited in the UNOP herbarium and the specimens present in the herbaria EVB, HCF, MBM and UNOP, as well as in the virtual herbaria Reflora and SpeciesLink, were analyzed. A total of 13 native species were recorded from Atlantic Forest, distributed in seven genera. Justicia was the most representative, with five species. In all, 12 new records were made for PARNA Iguaçu, of which eight are new records for Semideciduous Seasonal Forest. Of the species found, three are threatened with extinction, one of which is considered vulnerable and two are categorized as endangered, which reinforces the role of PARNA Iguaçu in in-situ conservation in the state of Paraná.
\end{abstract}

Key words: Araucaria Forest, Justicia, Ruellia, Semideciduous Seasonal Forest, Streblacanthus.

\section{Resumo}

As espécies de Acanthaceae são predominantemente associadas a ambientes florestais conservados como o Parque Nacional do Iguaçu, composto pelas Florestas Estacional Semidecidual e Ombrófila Mista. Este trabalho teve como objetivo realizar a flora de Acanthaceae do PARNA Iguaçu, com ilustrações botânicas, chave de identificação e descrições das espécies. Para isso foram realizadas coletas mensais de agosto de 2015 a julho de 2016 nas áreas de Céu Azul, Capanema e Foz do Iguaçu. Os indivíduos coletados foram depositados no herbário UNOP e os espécimes presentes nos herbários EVB, HCF, MBM e UNOP, assim como nos herbários virtuais Reflora e SpeciesLink, foram analisados. Foram encontradas 13 espécies nativas da Mata Atlântica, distribuídas em sete gêneros, sendo Justicia o mais representativo, com cinco espécies. Foram registradas 12 novas ocorrências para o Parque Nacional do Iguaçu, das quais oito são novos registros para Floresta Estacional Semidecidual. Dentre as espécies encontradas, três são ameaçadas de extinção, sendo uma categorizada como vulnerável e duas em perigo de extinção, o que reforça o papel do PARNA Iguaçu na conservação in-situ no estado do Paraná.

Palavras-chave: Floresta Ombrófila Mista, Justicia, Ruellia, Floresta Estacional Semidecidual, Streblacanthus.

\section{Introduction}

Lamiales is a monophyletic order and Acanthaceae is one of its most diverse family in Brazil with 39 genres and 453 species (BFG 2018).
The Acanthaceae family is monophyletic and divided into four subfamilies: Nelsonioideae Pfeiff., characterized mainly by lacking cystoliths and capsules without retinacula and numerous seeds; Thunbergioideae Kostel., which are mainly

\footnotetext{
${ }^{1}$ Universidade Estadual Paulista Júlio Mesquita Filho, Depto. Botânica, Rio Claro, SP, Brazil. ORCID: <https://orcid.org/0000-0002-0594-3257>.

${ }^{2}$ Pontifícia Universidade Católica do Paraná, Centro de Saúde e Biociências, Curso de Ciências Biológicas, Toledo, Paraná, Brazil. ORCID: <https://orcid. org/0000-0003-0380-9692>.

${ }^{3}$ Instituto de Botânica, São Paulo, SP, Brazil. ORCID: <https://orcid.org/0000-0001-6624-1884>.

${ }^{4}$ Universidade Estadual do Oeste do Paraná, Centro de Ciências Biológicas e da Saúde, Prog. Pós-graduação em Conservação e Manejo de Recursos Naturais, Cascavel, PR, Brazil. ORCID: <https://orcid.org/0000-0003-0449-2703>.

${ }^{5}$ Author for correspondence: janaine_h@hotmail.com
} 
lianas, (including Mendoncia Vell. ex Vand.); Acanthoideae Link., with a retinaculum and explosive capsules; and Avicenniodeae, which is monophyletic and sister to Thunbergioideae (McDade et al. 2008; Stevens 2012).

Acanthoideae is the subfamily with the largest number of species, approximately 4,000. It is characterized by having loculicidal capsules with retinacula, which are lignified and developed funiculi, hook shaped that support the seeds, and when the capsules open the elastic movement of the wall launches the seeds a certain distance (Witztum \& Schulgasser 1995). It is composed of a basal clade, the tribe Acantheae, which is sister to the other tribes, whose morphological synapomorphy is the presence of cystoliths and includes Ruelliae and Justiciae (McDade et al. 2008).

The distribution of Acanthaceae is mainly tropical, with about 4,000 species gathered in 220 genera (Stevens 2012). In Flora do Brasil (2020), 39 genera and 453 species are identified and for Paraná, 17 genera and 54 species.

They range from herbs to shrubs, lianas and rarely trees. They have simple, generally opposite leaves, flowers solitary or in inflorescences, bracts that are often colorful and showy (Kameyama 1995, 2006; Judd et al. 2009). Flowers in Acanthaceae usually have two or four didynamous stamens and sometimes, staminodes, bilocular ovary with two syncarpous carpels with axial placentation and a maximum of two rows of anatropous ovules in each carpel. The fruit is mostly a loculicidal capsule Generally, the flowers are colorful, and the inflorescences are axillary or terminal, in spikes of solitary flower or cymes, sometimes grouped in inflorescences of superior orders condensed in glomeruli or simple capitula (Ezcurra 1999).

Despite the difficulty in using vegetative characters for the identification of genera and species in Acanthaceae, a character that can help in the identification is the presence of cystoliths, which can be found in the genera Barleria, Ruellia, and Justicia, and are more easily observed in material already herborized with the aid of a stereomicroscope (McDade et al. 2000).

In spite of a previous checklist of the Acanthaceae of Paraná (Kameyama 2014), there are few studies of this family in Paraná. There is only one recent taxonomic study for Ruelliinae Nees, which is one of the largest subtribes of Acanthaceae, but this study only addresses the genera Dyschoriste Nees, Hygrophyla R.Br. and Ruellia L. (Silva 2011). For PARNA Iguaçu, one of the largest conservation units in the state, only Justicia brasiliana Roth is reported in the management plan (ICMBio 2018).

In view of the above, this work aimed to perform a floristic study of the Acanthaceae of PARNA Iguaçu, presenting morphological descriptions and phenology of the species, an identification key, and illustrations of the diagnostic characteristics to contribute to the knowledge of the family for the state.

\section{Material and Methods}

\section{Study area}

Iguaçu National Park (PARNA Iguaçu) is a conservation unit located in the state of Paraná, between the coordinates $25^{\circ} 05^{\prime}$ to $25^{\circ} 41^{\prime} \mathrm{S}$ and $53^{\circ} 40^{\prime}$ to $54^{\circ} 38^{\prime} \mathrm{W}$, with $185,262.5$ hectares of extension and a perimeter of $420 \mathrm{~km}$ (ICMBio 2018).

The climate of PARNA Iguaçu is classified as subtropical, with a hot summer, no dry season and little frost. The average temperature of the hottest month is above $22^{\circ} \mathrm{C}$, and that of the coldest month is below $18^{\circ} \mathrm{C}$ (Alvares et al. 2013; IAPAR 2010). In the PARNA Iguaçu area there is variation in altitude, the lowest part is the southern portion, with altitudes up to $200 \mathrm{~m}$ along the Iguaçu River and predominance of the Semideciduous Seasonal Forest (SSF), which covers most of the park. In the North the altitudes reach up to $600 \mathrm{~m}$ and is characterized as a transition area of Araucaria Forest (AF) and SSF (ICMBio 2018).

For the present work, PARNA Iguaçu was divided into three large areas, namely, Céu Azul (area 1, with transition of SSF/AF), Capanema (area 2, SSF) and Foz do Iguaçu (area 3, SSF) (Fig. 1).

\section{Collection and identification}

Trails were followed in the three different areas of PARNA Iguaçu. In area 1, six trails were visited, totaling $17 \mathrm{~km}$. In area 2, three trails were visited, about $64 \mathrm{~km}$. These were walked or accessed with the use of a motorboat, and along the Iguaçu Riverbank trail, the plants sighted were collected. In area 3, eight trails were traveled, totaling $16 \mathrm{~km}$ (Fig. 1).

Monthly collections were performed from August 2015 to July 2016, using the walking method described by Filgueiras et al. (1994) and detailed by Walter \& Guarino (2006). 


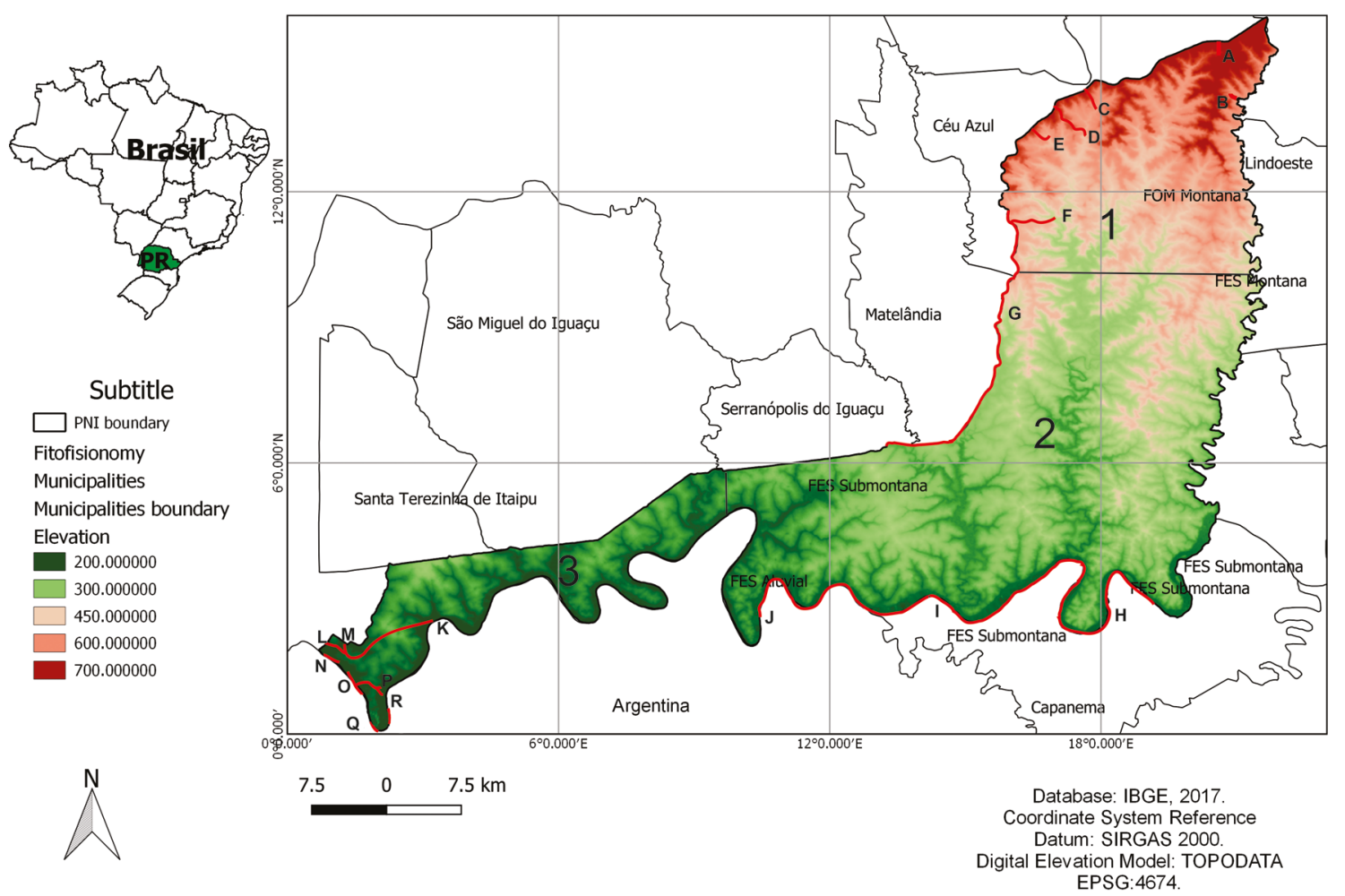

Figure 1 - Map of Iguaçu National Park with the trailed sampled. Céu Azul (area 1): A: Fazenda Rio Butu; B: Nascentes do Jumelo; C: Araucárias; D: Cachoeira Rio Azul; E: Manoel Gomes; F: Jacutinga. Capanema (area 2): G: Matelândia H: Banks of Rio Iguaçu on the Brazilian side; I: Cachoeira Rio Silva-Jardim; J: Ilha do Sol. Foz do Iguaçu (area 3): K: Poço Preto; L: Represa São João; M: Antiga Usina; N: Escola Parque; O: Macuco Safari; P: Bananeiras; Q: Cataratas; R: Hidrante. Source: the authors.

Whenever possible, at least three fertile branches were collected from each individual, which were prepared using herborization techniques (Bridson \& Forman 2010) for incorporation into the UNOP herbarium and duplicates sent to MBM and SP, acronyms according to Thiers (continuously updated). The collected specimens were photographed, described in the field and part of these samples were fixed in $70 \%$ alcohol for morphological studies in the laboratory.

Identification was performed through specific literature (Barroso 1991; Kameyama 1995; Ezcurra 1993, 2002; Wasshausen \& Wood 2004; Kameyama 2006) and comparison with samples at herbaria such as MBM and HCF (Thiers, continuously updated). The spelling of the scientific names and their authors follow The International Plant Names Index (IPNI 2016) and BFG 2018).

For the morphological descriptions, the vegetative and reproductive characteristics of the collected materials were analyzed with the aid of stereomicroscopy and the terminology was based on Weberling (1981) and Radford et al. (1974), in addition to the qualitative and quantitative characteristics observed in the herbarium samples of EVB, HCF, MBM and UNOP.

For the botanical illustrations, diagnostic characters were selected, present in the identification key and important for the identification of the species, which were illustrated in line drawing or in photographs of living plants

Data on geographical distribution were verified in the specialized literature, while comments on flowering, fruiting and area of occurrence in PARNA Iguaçu were based on the samples collected and materials examined.

Information on the conservation status of each of the species found in PARNA Iguaçu was obtained from the National Center for Conservation of Flora (CNCFlora 2016). 


\section{Results and Discussion}

In PARNA Iguaçu, 13 native species were found, distributed in seven genera of Acanthaceae. All species belong to the subfamily Acanthoideae, distributed in the tribes Acantheae (Aphelandra R.Br. and Stenandrium Nees), Ruellieae, (Hygrophila R.Br. and Ruellia
L.) and Justicieae (Justicia L., Pachystachys Nees and Poikilacanthus Lindau) (McDade et al. 2008).

Justicia was the most representative genus, with six species, followed by Ruellia with three. The other genera were represented by only one species each.

\section{Identification key to the species of Acanthaceae of PARNA Iguaçu}

1. Stamens 2.

2. Corolla up to $1.8 \mathrm{~cm}$ long.

3. Bracts inconspicuous, up to $1 \mathrm{~mm}$ long, inflorescence in panicle, corolla up to $0.5 \mathrm{~cm}$ long 5. Justicia comata

3'. Bracts conspicuous, over $3 \mathrm{~mm}$ long, inflorescence spicate, corolla over $1 \mathrm{~cm}$ long.

4. Subshrubs up to $0.50 \mathrm{~m}$ tall, bracts and bracteoles narrowly elliptical to linear.

4'. Shrubs, scandent, up to $1.5 \mathrm{~m}$ tall, bracts and bracteoles obovate 6. Justicia lythroides 9. Poikilacanthus glandulosus

2'. Corolla over $2.5 \mathrm{~cm}$ long.

5. Bracts and bracteoles lanceolate to obovate or elliptical, pubescent to densely pubescent, corolla never red.

6. Inflorescences exclusively terminal, corolla light to dark pink

..4. Justicia carnea

6'. Inflorescences axillary and terminal, corolla purple..... 7. Justicia ramulosa

5'. Bracts and bracteoles narrowly elliptical to linear, glabrescent to pubescent.

7. Branches always dilated in the internodes, visibly contracted above, glabrescent, corolla red 3. Justicia brasiliana

7'. Branches when dilated in internodes, never visibly contracted above, pubescent, corolla lilac..... 8. Pachystachys dubiosa

1'. Stamens 4.

8. Inflorescences verticillate cymes

2. Hygrophila costata

8'. Inflorescences spikes or cymes.

9. Cystoliths absent and anthers 4, monothecate.

10. Corolla short, bilabiate, orange or red with yellow hues ........ 1. Aphelandra longiflora

10'. Corolla infundibuliform, lilac or pink 13. Stenandrium mandioccanum

9'. Cystoliths present and anthers bithecate.

11. Bracts elliptical, obovate or ovate, corolla infundibuliform, lilac, blue or light pink..... 12. Ruellia erythropus

11'. Bracts and bracteoles narrowly elliptical to lanceolate up to $5 \mathrm{~mm}$ long, corolla tubular, red or magenta.

12. Corolla ventricose, more than $1 \mathrm{~cm}$ wide.

11. Ruellia brevifolia

12'. Corolla straight at the base up to $1 \mathrm{~cm}$ wide 10. Ruellia angustiflora

1. Aphelandra longiflora (Lindl.) Profice, Bradea, Boletim do Herbarium Bradeanum 10(1): 18. 2004.

Figs. 2a; 3a

Subshrubs, erect, up to $1 \mathrm{~m}$ tall. Branches cylindrical, never dilated in the internodes, pubescent, cystoliths absent. Leaves petiolate, petiole $2-4 \mathrm{~cm}$ long, blade narrowly elliptical to oblanceolate, $9-18 \times 2-5.5 \mathrm{~cm}$, pubescent on both surfaces, cystoliths absent, apex acute to acuminate, base attenuate, margin entire to slightly sinuous, pubescent. Inflorescences paniculate, terminal with spikes $1.5-12.5 \mathrm{~cm}$ long, sometimes with supernumerary spikes, inflorescence axes pubescent; bracts and bracteoles narrowly elliptical 

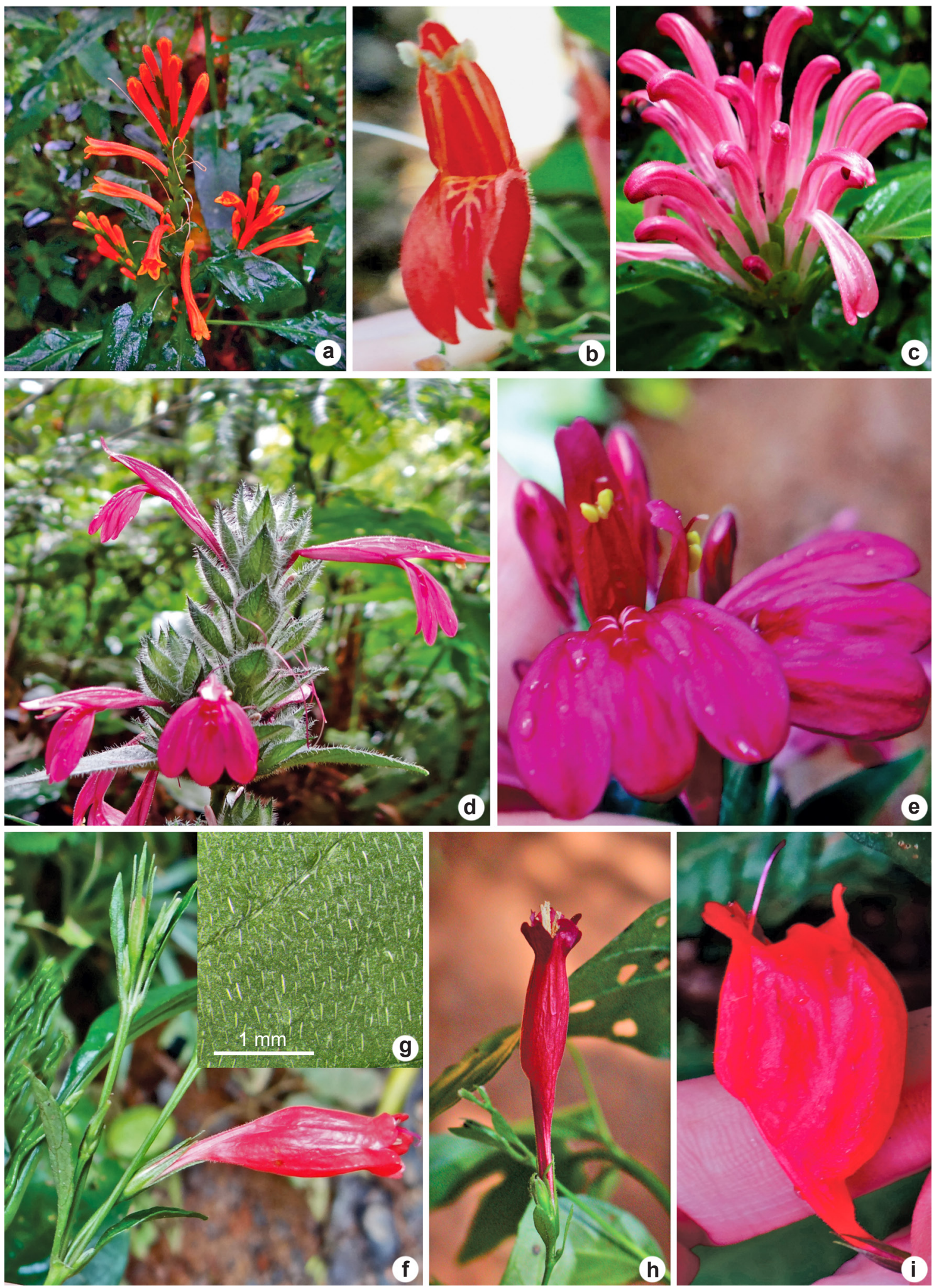

Figure 2 - a-i. Inflorescences in Acanthaceae - a. Aphelandra longiflora - inflorescence; b. Justicia brasiliana - flower; c. Justicia carnea - inflorescence; d-e. Justicia ramulosa - d. inflorescence; e. flower; f-h. Ruellia angustiflora - $\mathrm{f}$. inflorescence; g. detail of the cistolith on the leaf blade; h. flower; i. Ruellia brevifolia-flower. 
to lanceolate, 4-5 mm long, glabrescent. Calyx 5-lobed, lobes lanceolate, 4-5 mm long, pubescent; corolla orange-red, throat and mid-region of the lobes yellow, pubescent, corolla short, bilabiate, straight, 3-4 cm long, 2.5-3 cm long, upper lip 4-5 mm long, bilobate, oblong, lower lip 4-6 $\mathrm{mm}$ long, trilobate, lobes 2-4 $\mathrm{mm}$ long, lateral lobes $2-2.5 \mathrm{~mm}$ wide, central lobe $1-2 \mathrm{~mm}$ wide, ovate; stamens 4 , exserted, trichomes present at the base, anthers monothecous, base not sagittate; nectariferous disk present; ovary pyriform, ca. 3 $\mathrm{mm}$ long, glabrous. Fruits capsules, ellipsoid, 1.5-2 $\mathrm{cm}$ long. Seeds 5, flattened.

Selected material: Capanema, margem do Rio Iguaçu, próximo ao porto, 24.V.1949, fl., A.P. Duarte et al. 1876 (MBM). Silva Jardim, 22.III.2016, fl., J.K. Hammes et al. 82 (UNOP). Céu Azul, trilha da Jacutinga, 08.VI.2016, fl., J.K. Hammes et al. 120 (UNOP). Rio Azul, 11.II.2015, fl., M.G. Caxambu et al. 7241 (HCF). Foz do Iguaçu, trilha das Bananeiras, 7.VII.2016, fl., J.K. Hammes et al. 138 (UNOP). Poço Preto, 21.IV.2007, fl., L.G. Temponi et al. 453 (UNOP); 28.VI.2007, fl., E. Barbosa et al. 2208 (UNOP, MBM, HCF); 30.III.2011, fl., M. Lautert et al. 06 (UNOP); 24.III.2016, fl., J.K. Hammes et al. 105 (UNOP); represa São João, 12.X.2009, fl., L.G. Temponi et al. 703 (UNOP); represa, 21.V.2015, fl., M.G. Caxambu et al. 6349 (HCF); Rio São João, 18.III.2017, fl., L.C. Pires 869 (EVB); Rio Floriano, 19.III.2004, fl., O.S. Ribas et al. 6055 (MBM); 5.VIII.2007, fl., A.M. Rodolfo et al. 32 (UNOP).

Additional material: BRASIL. PARANÁ: Capitão Leonidas Marques, próximo ao Parque Nacional do Iguaçu, 29.VI.2004, fl., P. Labiak et al. 3342 (MBM); margens do Rio Gonçalves Dias, 28.VII.2016, fl. and fr., J.K. Hammes et al. 98 (MBM).

This species can be found in Argentina, Bolivia and Brazil, being exclusively tropical (Profice \& Andreata 2011). In Brazil, it occurs in the North, Central-West, Southeast and South regions, in areas of Riparian or Gallery Forest, Upland Forest, Ombrophilous Forest and Restinga (BFG 2018). According to the CNCFlora (2016), this species is characterized as least concern. In PARNA Iguaçu it occurs in the three areas, including SSF and AF, along almost all trails and was found with flowers from February to October and fruits in the month of July.

Aphelandra longiflora is mainly recognized by the spike or panicula with congest flowers, short 2-labiate, reddish orange corolla with a yellow throat and middle region.

2. Hygrophila costata Nees \& T. Nees, Plantarum, in Horto Medico Bonnensi Nutritarum, Icones Selectae 2: 7-8, pl. 3. 1824.
Herbs erect, up to $1.5 \mathrm{~m}$ tall. Branches quadrangular, never dilated in the internodes, glabrescent, cystoliths present. Leaves sessile, blade narrowly elliptical to lanceolate, 4-14 $\times$ 1-3 cm, adaxial surface glabrescent and abaxial surface pubescent along veins, cystoliths present, apex acuminate, base attenuate, margin entire, glabrescent. Inflorescences cymose, verticillate, axillary, inflorescence axes pubescent; bracts and bracteoles lanceolate, 13-14 mm long, pubescent. Flowers sessile; calyx 5-lobed, lobes narrowly lanceolate to linear, 5-8 $\mathrm{mm}$ long, glabrescent; corolla white to lilac, throat with lilac spots, glabrous, bilabiate, straight, $1-1.1 \mathrm{~cm}$ long, tube 0.4-0.5 cm long, upper lip 3-4 mm long, bilobate, oblong, lower lip 3-4 mm long, trilobate, lobes 1-2 $\mathrm{mm}$ long, lateral lobes $1 \mathrm{~mm}$ wide, central lobe 1 mm wide, ovate; stamens 4, exserted, trichomes base glabrous, anthers dithecous, thecae inserted at the same height at the connective, divergent, base sagittate; nectariferous disk absent; ovary cylindrical, about $1 \mathrm{~mm}$ long, glabrous. Fruits capsules, $0.7-1 \mathrm{~cm}$ long. Seeds 5, elliptical.

Examined material: Capanema, margem do Iguaçu, 16.IV.1964, fl. and fr., G. Hatschbach 11203 (MBM); 3.VI.2006, fl. and fr., P.H. Labiak 3836 (MBM). Céu Azul, 12.XI.2015, fl., E.L. Siqueira \& M.P. Chagas et al. 1779 (HCF). Foz do Iguaçu, Cataratas do Iguaçu, 15.X.1991, fr., A.C. Cervi 3414 (MBM); represa São João, 27.I.2010, fl. and fr., L.G. Temponi et al. 707 (UNOP).

Additional material: BRASIL. PARANÁ: Quatro Barras, 7.II.2010, fl. and fr., R. Ristow et al. 444 (MBM).

Hygrophila costata can be found from Mexico to Argentina (Wasshausen 1995) and in Brazil occurs in the North, Northeast, CentralWest, Southeast and South, in Riparian Forest and Ombrophilous Forest (BFG 2018). In PARNA Iguaçu it can be found in the three areas, Céu Azul, Capanema and Foz, in SSF and AF, in more humid places. This species blooms and bears fruit practically all year round.

This species can be recognized for having verticillate cymes and corolla from white to lilac, generally found in humid areas, near watercourses.

3. Justicia brasiliana Roth, Sp. Pl. Nov. 17. 1821.

Figs. $2 b ; 3 b$

Subshrubs, erect or decumbent, up to $2 \mathrm{~m}$ tall. Branches subquadrangular to cylindrical, dilated in the internodes, visibly contracted above the internodes, glabrescent with a longitudinal band of trichomes, cystoliths obscure to conspicuous. 


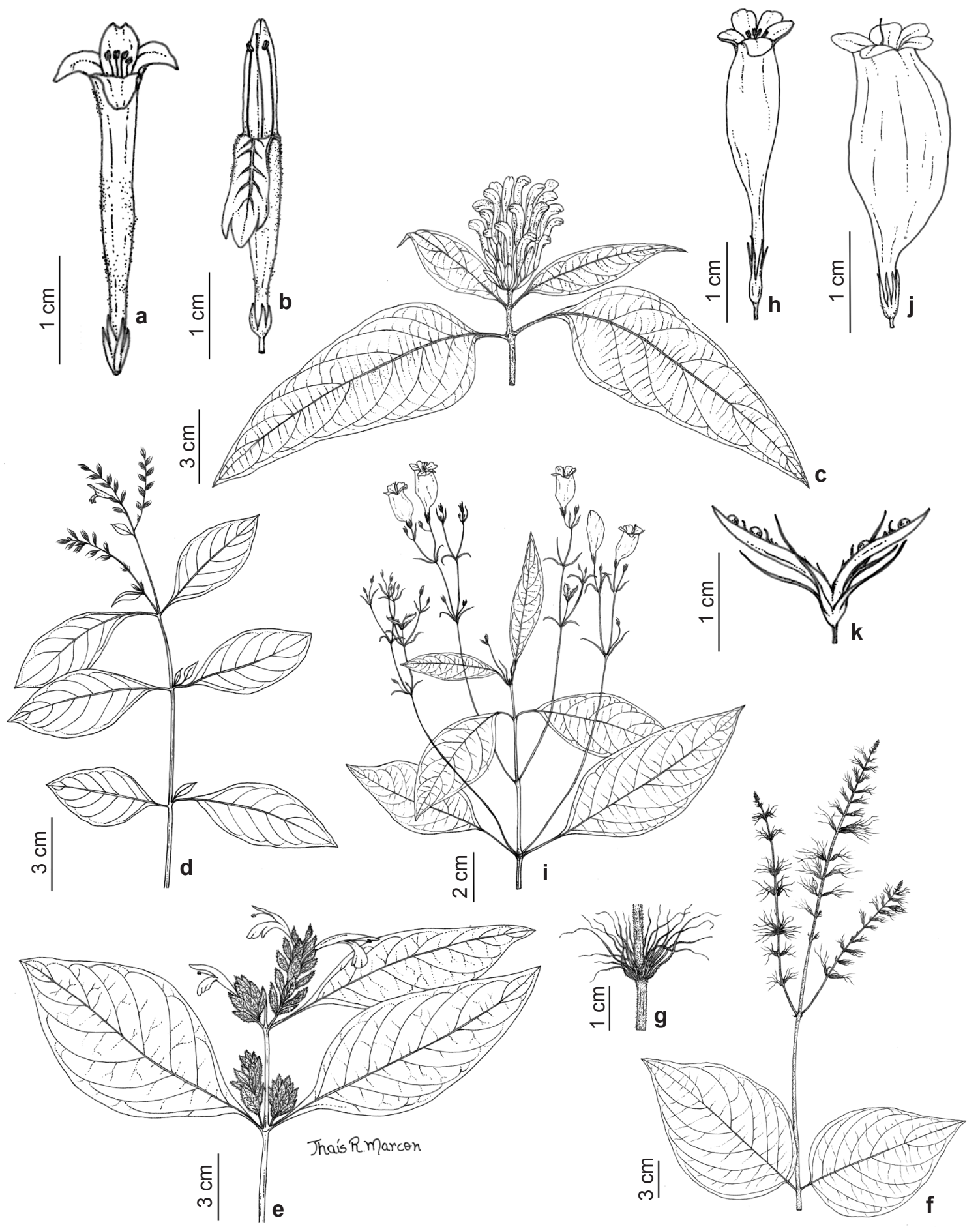

Figure 3 - a-k. Diagnostic characteristics of Acanthaceae species - a. Aphelandra longiflora - flower; b. Justicia brasiliana - flower; c. Justicia carnea - habit and inflorescence; d. Justicia lyithroides - habit; e. Justicia ramulosa - inflorescence and tomentose bracts; f-g. Pachystachys dubiosa - f. habit; g. the linear bracts in the inflorescence; h. Ruellia angusiflora - flower; i-k. Ruellia brevifolia - i. habit; j. flower; k. fruit. 
Leaves, petiole up to $1 \mathrm{~cm}$ long, blade lanceolate to narrowly elliptical, 6-13 $\times 1-3 \mathrm{~cm}$ (upper leaves considerably smaller than the lower ones), pubescent on the adaxial surface and glabrous on the abaxial surface, cystoliths absent, apex acuminate, base attenuate decurrent along the petiole, margin entire to slightly sinuous, glabrous. Inflorescences spicate, subsessile, axillary, opposite; inflorescence axes pubescent; bracts and bracteoles narrowly elliptical to linear 4-6 mm long, glabrescent. Flowers, calyx 5-lobed, lobes lanceolate 2.9-3.1 $\mathrm{mm}$ long, pubescent; corolla red externally, with whitish spots internally, bilabiate, straight, 2.9-3.8 cm long, tube 2-2.5 cm long, upper lip 0.9-1 cm long, bilobate, narrowly ovate, lower lip $0.8-1 \mathrm{~cm}$ long, trilobate, lobes $2-3 \mathrm{~mm}$ long, lateral lobes about $1 \mathrm{~mm}$ wide, central lobe 1-2 mm wide, rounded; stamens 2, extended to the tip of the lips, trichomes present at the base, anthers dithecous, thecae inserted at the same height as the connective, parallel, base not sagittate; nectariferous disk present; ovary cylindrical, about $2 \mathrm{~mm}$ long, glabrescent. Fruits clavate capsules, $0.8-1.5 \mathrm{~cm}$ long. Seeds 3, cordate, flattened.

Selected material: Capanema, próximo à antiga estrada do Colono, 20.III.2014, fl., M.L. Toderke et al. 188 (UNOP). Silva Jardim, 22.II.2016, fl. and fr., J.K. Hammes et al. 83 (UNOP); trilha da Taquara, 7.XI.2013, fl., M. Lautert et al. 366 (UNOP). Céu Azul, trilha Manoel Gomes, 01.X.2015, fl. and fr., J.K. Hammes et al. 70 (UNOP); trilha do Rio Azul, 11.II.2016, fl., M.G. Caxambu et al.7235 (HCF). Foz do Iguaçu, trilha da antiga usina, 6.IV.2016, fl. and fr., J.K. Hammes et al. 112 (UNOP). Linha Martins, 15.X.2015, fl., M.G. Caxambu et al. 6980 (HCF); trilha do Macuco, 7.VII.2016, fl., J.K. Hammes et al. 129 (UNOP); margens da BR-469, 22.V.2015, fl. and fr., M.G. Caxambu et al. 6448 (HCF); Poço Preto, 21.IV.2007, fr., L.G. Temponi et al. 447 (UNOP); 30.III.2011, fl., M. Lautert et al. 09 (UNOP); 24.III.2016, fl. and fr., J.K. Hammes et al. 102 (UNOP); trilha da represa São João, 6.IV.2016, fl. and fr., J.K. Hammes et al. 108 (UNOP); trilha da Educação Ambiental, 9.X.2009, fl., L.G. Temponi et al. 565 (UNOP, MBM); Rio Floriano, 19.III.2004, fl., O.S. Ribas et al. 6070 (MBM); trilha de Visitação, 7.VII.2016, fl., J.K. Hammes et al. 152 (UNOP).

It can be found in Brazil, Paraguay and Argentina (Ezcurra 2002). In Brazil it occurs in the Central-West, Southeast and South and is found in Riparian Forest and Ombrophilous Forest (BFG 2018). It occurs in several physiognomies of the Atlantic Forest and in several conservation units, with great abundance in southern Brazil and, therefore, characterized as of little concern (CNCFlora 2016). It occurs in the three areas of
PARNA Iguaçu, in SSF and AF along practically all trails and was found from February to November with flowers and fruits.

Justicia brasiliana is recognized for having a distinctly bilabiate, red corolla and subsessile spikes.

4. Justicia carnea Lindl., Edwards's Botanical Register 17: pl. 1397. 1831. Figs. 2c; 3c

Herbs or subshrubs, erect, up to $1.5 \mathrm{~m}$ tall. Branches subquadrangular, never dilated in the internodes, pubescent, cystoliths absent. Leaves, petiole up to $2 \mathrm{~cm}$ long, blade elliptical to ovate, $8-16.5 \times 3-8.5 \mathrm{~cm}$, pubescent on the adaxial surface and with trichomes on the abaxial surface along veins, cystoliths present, apex acuminate, base attenuate, decurrent along the petiole, margin entire, glabrescent. Inflorescences paniculate, congested, subsessile, terminal, solitary, inflorescence axes tomentose; bracts and bracteoles lanceolate to obovate, $1.9-1.2 \mathrm{~cm}$ long, pubescent. Flowers sessile; calyx 5-lobed, lobes lanceolate, 9-11 $\mathrm{mm}$ long, glabrescent; corolla bright to dark pink externally, without differentiation at the base, bilabiate, straight, $4.5-5 \mathrm{~cm}$ long, tube $2.5-3 \mathrm{~cm}$ long, upper lip 1-1.2 $\mathrm{mm}$ long, bilobate, lobes about $1 \mathrm{~mm}$ long, oblong, lower lip 4-5 mm long, trilobate, lobes 3-4 mm long, lateral lobes 2-4 $\mathrm{mm}$ wide, central lobe about $3 \mathrm{~mm}$ wide, rounded; stamens 2, included below the upper lip, trichomes present at the base, anthers dithecous, thecae inserted at different heights in the connective, parallel, base not sagittate; nectariferous disk present; ovary cylindrical, about $3 \mathrm{~mm}$ long, glabrescent. Fruits not observed.

Selected material: Foz do Iguaçu, Poço Preto, 7.X.2007, fl., L.G. Temponi et al. 495 (UNOP); 11.X.2009, fl., L.G. Temponi et al. 644 (UNOP, MBM); 30.III.2011, fl., M. Lautert et al. 05 (UNOP); 13.X.2011, fl., J.A. Lombardi et al. 8767 (UNOP); 5.VI.2015, fl., M.G. Caxambu et al. 6512 (HCF); 25.II.2016, fl., M.G. Caxambu et al. 7256 (HCF); 25.II.2016, fl., M.G. Caxambu et al. 7266 (HCF); 24.III.2016, fl., J.K. Hammes et al. 106 (UNOP).

This species can be found in Argentina, Paraguay, Colombia, Ecuador and Brazil (Ezcurra 2002; Profice 2013). In Brazil, it is registered in the Southeast and South, occurring in the Semideciduous and Ombrophilous Seasonal Forests (BFG 2018). This species was not evaluated for conservation status. In PARNA Iguaçu, Justicia carnea only occurs in Foz do Iguaçu (SSF), on the Poço Preto trail. In the study area it blooms mainly from October to March, but it was also collected with flowers in June. 
Justicia carnea is the only species in this area with exclusively terminal, subsessile, thyrse inflorescence.

5. Justicia comata (L.) Lam., Encyclopédie Méthodique, Botanique 1: 632. 1785.

Herbs, erect, up to $0.45 \mathrm{~m}$ tall. Branches subquadrangular, never dilated in the internodes, glabrescent, cystoliths present. Leaves, sessile to subsessile, blade narrowly elliptical to lanceolate, $3.5-8.3 \times 1-2 \mathrm{~cm}$, glabrescent on both surfaces, cystoliths present, apex acuminate, base attenuate, margin entire, glabrescent. Inflorescences axillary and terminal with several spikes at the same node of the inflorescence axes, terminal ones forming a panicle, one per axil, stems $1.2-6 \mathrm{~cm}$ long, axillary and terminal; inflorescence axes pubescent; bracts and bracteoles lanceolate, $0.5-1$ $\mathrm{mm}$ long, glabrescent. Flowers, calyx 5-lobed, lobes lanceolate, 1.8-2.0 mm long, pubescent; corolla whitish to pinkish, throat with lilac spots, bilabiate, straight, $0.4-0.5 \mathrm{~cm}$ long, tube $0.2-0.3$ $\mathrm{cm}$ long, upper lip $2 \mathrm{~mm}$ long, bilobate, elliptical, lower lip 3-3.2 mm long, trilobate, lobes $0.8-1 \mathrm{~mm}$ long, lateral lobes $0.5-0.6 \mathrm{~mm}$ wide, central lobe $0.8-1 \mathrm{~mm}$ wide, widely ovate; stamens 2 , exserted, glabrous, anthers dithecous, thecae inserted at different heights in the connective, divergent, base not sagittate; nectariferous disk present; ovary ovoid, 1-1.2 mm long, glabrous. Fruits clavate capsules, $0.4-0.5 \mathrm{~cm}$ long. Seeds 3.

Examined material: Foz do Iguaçu, barragem Rio São João, 16.IV.1964, fl., G. Hatschbach 11202 (MBM); 19.X.1991, fl., A.C. Cervi et al. 3443 (MBM); 21.VI.2015, fl. and fr., M.G. Caxambu et al. 6365 (HCF).

This species is widely distributed throughout the Neotropical region (Ezcurra 2002) and in Brazil it can be found in the North, Northeast, CentralWest, Southeast and South, only in Ombrophilous Forest (BFG 2018). Justicia comata was not evaluated for conservation status. Although it is identified as a species of AF, in the study area it was found only in Foz do Iguaçu on the São João Dam Trail, a region of SSF. This species blooms in October, April and June, and was found with fruit only in June.

Justicia comata is recognized for having a panicle of verticilate spikes.

6. Justicia lythroides (Nees.) V.A.W. Graham., Kew Bulletin 43(4): 603. $1988 . \quad$ Fig. 3d

Subshrub, erect or decumbent, up to $0.50 \mathrm{~m}$ tall. Branches subquadrangular to quadrangular, never dilated in the internodes, glabrescent, with a longitudinal band of trichomes, cystoliths present. Leaves, petiole up to $0.8 \mathrm{~cm}$ long, blade elliptical to ovate, $2.8-5.6 \times 1.3-2.7 \mathrm{~cm}$, glabrescent on both surfaces mainly on the central vein, cystoliths present, apex acuminate, base attenuate, decurrent along the petiole, margin entire to slightly sinuous, glabrescent. Inflorescences paniculate, composed of secundiflorous spikes, some flowers opposite, axillary; inflorescence axes pubescent with a longitudinal band of trichomes; bracts and bracteoles narrowly elliptical to linear 3-4 $\mathrm{mm}$ compr, long, glabrescent. Flowers sessile; calyx 4-lobed, lobes lanceolate, 5-6 mm long, pubescent; corolla whitish externally, purple with white lines internally, bilabiate, straight, 1.0-1.2 $\mathrm{cm}$ long, tube $0.5-0.7 \mathrm{~cm}$ long, upper lip $0.4-0.5$ $\mathrm{cm}$ long, bilobate, narrowly elliptical, lower lip $0.4-0.5 \mathrm{~cm}$ long, trilobate, lobes $4.0-5.0 \mathrm{~mm}$ long, lateral lobes about $2 \mathrm{~mm}$ wide, central lobe 2-3 mm wide, rounded; stamens 2 , extended to the tip of the lips, trichomes present at the base, anthers dithecous, inferior thecae sterile, reduced to a slight thickening on the filament; nectariferous disk present; ovary cylindrical, about $1 \mathrm{~mm}$ long, glabrescent. Fruits clavate capsules, $0.4-0.5 \mathrm{~cm}$ long. Seeds 4.

Examined material: Foz do Iguaçu, próximo às Cataratas do Iguaçu, 2.VII.2015, fl., M.G. Caxambu 6611 (HCF); trilha da visitação, 7.VII.2016, fl., J.K. Hammes 156 (UNOP).

It is distributed in South America, exclusively in Brazil, Argentina and Paraguay (Ezcurra 2002). In the national territory it is found only in the South and Southeast, in Ombrophilous Forest (BFG 2018). The National Center for the Conservation of Flora (2016) characterizes this species as of little concern, but in PARNA Iguaçu it was found only on the Cataratas Trail (SSF), with flowering in July.

Justicia lythroides is recognized for having an externally whitish and internally purple corolla with white spots and cystoliths in the stems.

7. Justicia ramulosa (Morong) C. Ezcurra, Boletín de la Sociedad Argentina de botánica 25: 350. 1988.

Figs. 2d-e; 3e

Subshrubs, erect, up to $1.6 \mathrm{~m}$ tall. Branches, cylindrical to subquadrangular, never dilated in the internodes, pubescent, cystoliths absent. Leaves, petiole $0.5-1.0 \mathrm{~cm}$ long, blade ovate to rhombic, 4.5-14 × 2.5-6 cm long, glabrescent on both surfaces, cystoliths present, apex acute, 
base attenuate, margin entire, glabrescent. Inflorescences spicate, sessile, axillary and terminal; inflorescence axes pubescent; bracts and bracteoles elliptical, 7-11 mm long, thickly pubescent. Flowers, calyx 5-lobed, lobes lanceolate to linear, 4-6 mm long, pubescent; corolla purple, throat with a white straight line and lateral spots, bilabiate, straight, $3.2-4 \mathrm{~cm}$ long, $2.5-3 \mathrm{~cm}$ long, upper lip 6-11 mm long, bilobate, narrowly elliptical, lower lip 5-13 mm long, trilobate, lobes 5-6 $\mathrm{mm}$ long, lateral lobes $2-4 \mathrm{~mm}$ wide, central lobe 2-4 mm wide, oblong; stamens 2, exserted, without trichomes at the base, anthers dithecous, thecae inserted at different heights in the connective, divergent; nectariferous disk present; ovary slightly pyriform, 2-3 mm long, glabrescent. Fruits not observed.

Selected material: Foz do Iguaçu, trilha das Bananeiras, 7.VII.2016, fl., J.K. Hammes et al. 146 (UNOP); trilha do Macuco, 7.VII.2016, fl., J.K. Hammes et al. 130 (UNOP); margem do Rio Iguaçu, 21.V.2010, fl., L.G. Temponi et al. 862 (UNOP); Poço Preto, 25.V.2007, fl., A.M. Rodolfo et al. 15 (UNOP); trilha da represa, 21.V.2015, fl., M.G. Caxambu et al. 6352 (HCF); trilha da visitação, 7.VII.2016, fl., J.K. Hammes et al. 149 (UNOP).

This species can be found in Peru, South and Central-West Brazil, Bolivia, Paraguay and Argentina (Ezcurra 2002). In Brazil it only occurs in Mato Grosso and Paraná, in the domains of Cerrado and Deciduous Seasonal Forest (BFG 2018). According to the National Center for the Conservation of Flora (2016), the species is considered vulnerable, possibly due to the low efficiency of the pollinator, expressed by the small amount of pollen recorded in hummingbirds, and may show stress due to the incidence of threats. However, in PARNA Iguaçu this species occurs only in SSF, in the areas of Foz do Iguaçu and Capanema and can be found with flowers in the months of May and June.

Justicia ramulosa is recognized by the pubescent to densely pubescent bracts and corolla with purple coloration, throat with a straight line and white lateral spots. It was described as Chaetothylax vestitus Rizzini, for ParNa Iguaçu by Rizzini (1952), and it was mistakenly considered by Ezcurra (2019) as synonymous with Justicia goudotii V.A.W. Graham, but should therefore be treated as synonymous with Justicia ramulosa, as already discussed by Profice (2010). In addition Justicia araucariensis Profice, a new name for Chaetothylax vestitus, should also be considered synonymous with Justicia ramulosa.
8. Pachystachys dubiosa (Lindau) A.L.A. Côrtes Nordic Journal of Botany 34: 526. 2016.

Fig. 3f-g

Shrubs, erect, up to $2.5 \mathrm{~m}$ tall. Branches, cylindrical, sometimes dilated in the internodes, pubescent, cystoliths absent. Leaves, petiole 0.6-7 cm long, blade elliptical to ovate, 8-19 $\times$ $4.5-11 \mathrm{~cm}$ long, glabrescent on the adaxial surface, glabrous on the abaxial surface and pubescent along the veins, cystoliths present, apex acuminate, base obtuse to asymmetrical, margin entire, pubescent. Inflorescences spicate, sessile, axillary; inflorescence axes pubescent; bracts and bracteoles linear, 5-21 mm long, pubescent. Flowers, calyx 5-lobed, lobes lanceolate 5-15 mm long, pubescent; corolla from pink to lilac, throat whitish, pubescent, bilabiate, straight, $2.5-2.7 \mathrm{~cm}$ long, tube $2-2.2 \mathrm{~cm}$ long, upper lip 4-5 mm long, bilobate, narrowly elliptical, lower lip 4-6 mm long, trilobate, lobes 3-5 mm long, lateral lobes $2-3 \mathrm{~mm}$ wide, central lobe 2-3 mm wide, elliptical; stamens 2, exserted, without trichomes at the base, anthers dithecous, thecae inserted at the same height in the connective, parallel, base sagittate; nectariferous disk present; ovary pyriform, $2-3 \mathrm{~mm}$ long, glabrescent. Fruits clavate capsules, $1-1.5 \mathrm{~cm}$ long. Seeds 2, ellipsoid. Selected material: Céu Azul, trilha Manoel Gomes, 1.X.2016, fl. and fr., J.K. Hammes et al. 71 (UNOP). Jacutinga, 6.IX.2011, fl. and fr., L. Boff et al. 12 (UNOP). Foz do Iguaçu, Bananeiras, 12.X.2009, fl. and fr., L.G. Temponi et al. 671 (UNOP, MBM, HCF); 14.II.2013, fl. and fr., M.L. Toderke et al. 52 (UNOP); 7.VII.2016, fl., J.K. Hammes et al. 143 (UNOP); Parque Nacional do Iguaçu, 17.IV.1964, fl. and fr., G. Hatschbach 11211 (MBM); 5.VIII.2004, fl. and fr., E. Barbosa \& E.F. Costa 965 (MBM); 23.VIII.2004, fl. and fr., E. Barbosa \& E.F. Costa 975 (MBM); Poço Preto, 12.X.1986, fl. and fr., G. Hatschbach 50625 (MBM); 11.X.2009, fl. and fr., L.G. Temponi et al. 636 (UNOP, MBM); 30.III.2011, fl. and fr., M. Lautert et al. 08 (UNOP); trilha da visitação, 7.VII.2016, fl., J.K. Hammes et al. 154 (UNOP).

This species can be found in lower elevations of the Andes up to Paraguay (Wasshausen \& Wood 2004) and in Brazil it only occurs in Mato Grosso do Sul and Paraná in areas of Ombrophilous Forest (BFG 2018). In this state it can only be found in PARNA Iguaçu and under its synonym, Streblacanthus dubiosus, is indicated in the CNCFlora (2016) as threatened with extinction, mainly due to its difficulty of dispersion and the high degradation of habitats. Inside PARNA Iguaçu, it can be found in both forest types, in Foz do Iguaçu (SSF) and Céu Azul (AF) and its reproductive period was observed from July to October and from February to April. 
Pachystachys dubiosa can be differentiated from the other species in the area by the linear bracts and an unusual long and narrow corolla tube.

\section{Poikilacanthus glandulosus (Nees) Ariza Kurtziana 17: 159. 1984.}

Shrubs, scandent, up to $1.5 \mathrm{~m}$ tall. Branches subquadrangular, never dilated in the internodes, pubescent, cystoliths absent. Leaves, petiole $0.4-1.5$ $\mathrm{cm}$ long, blade lanceolate to oblong, 2-7.2 × 0.9-2.3 $\mathrm{cm}$, glabrescent on both surfaces, pubescent along the veins, cystoliths present, apex acuminate, base obtuse to rounded, margin entire, pubescent. Inflorescences spicate, subsessile, axillary or terminal; inflorescence axes hirsute; bracts and bracteoles obovate 1-10 mm long, pubescent. Flowers, calyx 5-lobed, lobes lanceolate, 5-15 mm long, glabrescent; corolla whitish, throat whitish, pubescent, bilabiate, straight, $2.5-2.7 \mathrm{~cm}$ long, tube 1.6-1.9 cm long, upper lip 0.9-11 mm long, bilobate, narrowly ovate, lower lip 8-10 mm long, trilobate, lobes 1-2 mm long, lateral lobes 1-2 mm wide, central lobe 1-2 mm wide, oblong; stamens 2 , exserted, with trichomes at the base, anthers dithecous, thecae inserted at different heights in the connective, almost parallel, base sagittate; nectariferous disk present; ovary pyriform, 2-3 $\mathrm{mm}$ long, glabrous. Fruits clavate capsules, 1-1.3 $\mathrm{cm}$ long. Seeds 2 , flattened.

Selected material: Foz do Iguaçu, beira da BR, 16.I.2019, fl., J.K. Hammes et al. 179 (UNOP); nova trilha de bicicleta próximo à portaria, 25.II.2016, fl. and fr., M.G. Caxambu et al. 7274 (HCF; UNOP); trilha do Macuco, 16.I.2019, fl., J.K. Hammes et al.176 (UNOP).

This species can be found in Argentina, Brazil, Paraguay and Uruguay (Tropicos 2019) and in Brazil occurs in the Southeast and South in São Paulo, Paraná and Santa Catarina in areas of Ombrophilous Forest (BFG 2018). This species was not assessed for conservation status. Inside PARNA Iguaçu it can be found in Foz do Iguaçu (SSF) in Semideciduous Seasonal Forest, its reproductive period was observed from January to February.

Poikilacanthus glandulosus is recognized for the habit, a scandent shrub, for its dense and obovate bracts, terminal and axillary inflorescences and whitish flowers.

10. Ruellia angustiflora (Nees) Lindau ex Rambo, Iheringia, Série Botânica 12: 23. 1964.

Figs. 2f-g; $3 \mathrm{~h}$

Shrubs, erect, up to $2 \mathrm{~m}$ tall. Branches quadrangular, never dilated in the internodes, glabrescent with trichomes only on the nodes, cystoliths absent. Leaves, petiole $0.7-4 \mathrm{~cm}$ long, blade narrowly elliptical to elliptical, 5-19 × 2-5.4 $\mathrm{cm}$, glabrescent on the adaxial surface and with trichomes only along the abaxial surface central vein, cystoliths present on the adaxial surface, apex acuminate, base attenuate, margin entire to crenate, glabrous. Inflorescences cymose, subsessile, axillary, alternate; inflorescence axes glabrescent; bracts and bracteoles narrowly elliptical, 1-2.5 $\mathrm{cm}$ long, glabrescent. Flowers, pedicel 0.4-1.5 $\mathrm{cm}$ long; calyx 5-lobed, lobes narrowly triangular to lanceolate, 5-10 mm long, pubescent; without differentiation on the expanded and unexpanded portion, tubular, straight, $3-4 \mathrm{~cm}$ long, tube $2.5-3.5$ cm long, lobe 2-4 mm long; stamens 4, included, trichomes present along the entire filament, anthers dithecous, parallel, base sagittate; nectariferous disk present; ovary cylindrical, about $5 \mathrm{~mm}$ long, glabrescent. Fruits clavate capsules, about 1.5-2 cm long. Seeds 7, suborbicular.

Selected material: Capanema, antiga estrada do Colono, 2.VIII.2004, fl., E. Barbosa \& E.F. Costa 954 (MBM). Silva Jardim, 22.II.2016, fl., J.K. Hammes et al. 84 (UNOP). Céu Azul, trilha da cachoeira do Rio Azul, 14.IX.2015, fl., J.K. Hammes et al. 67 (UNOP); estrada de terra Céu Azul, 13.XI.2015, fl., E.L. Siqueira \& M.P. Chagas 1809 (HCF); trilha da Jacutinga, 08.VI.2016, fl., J.K. Hammes et al. 119 (UNOP); trilha das nascentes do Jumelo, 27.IV.2016, fl., J.K. Hammes et al. 116 (UNOP). Foz do Iguaçu, trilha da antiga usina, 6.IV.2016, fl., J.K. Hammes et al. 113 (UNOP); descida para o Rio Iguaçu, 19.IX.2001, fl., G. Hatschbach et al. 72403 (MBM). Macuco, 1.XII.2011, fl., L.G. Temponi \& M.T. Martinez 1069 (UNOP); 3.IX.2015, fl. and fr., E.L. Siqueira et al. 1589 (HCF); 7.VII..2016, fl., J.K. Hammes et al. 126 (UNOP); 7.VII.2016, fl., J.K. Hammes et al. 128 (UNOP); margens da BR-277, 18.VI.2015, fl. and fr., M.G. Caxambu et al. 6552 (HCF); margens da BR-469, 14.VIII.2015, fl., M.G. Caxambu et al. 6769 (HCF); Parque Nacional do Iguaçu, 5.X.2006, fl., O.S. Ribas et al. 7444 (MBM); Poço Preto, 10.XI.1963, fl., E. Pereira et al. 7810 (MBM); 2.X.2006, fl. and fr., O.S. Ribas et al. 7381 (MBM); 24.III.2016, fl., J.K. Hammes et al. 103 (UNOP); represa São João, 5.IX.2013, fl., M.L. Toderke et al. 93 (UNOP); Rio São João, 22.V.2015, fl., M.G. Caxambu et al. 6430 (HCF); trilha da represa, 13.VIII.2015, fl. and fr., M.G. Caxambu et al. 6740 (HCF).

It occurs in South America, Brazil, Paraguay, Uruguay and Argentina (Ezcurra 1993). In the national territory it occurs in the Central-West, Southeast and South in Cerrado, Semideciduous Seasonal Forest, Ombrophilous Forest and Araucaria Forest (BFG 2018). This species was not evaluated for conservation status. In PARNA 
Iguaçu, Ruellia angustiflora occurs in the three areas in SSF and AF and blooms practically all year round, being found with fruit in the months of June, August, September and October.

Ruellia angustiflora can be recognized by its subsessile cymes and the red or magenta, tubular corolla. It is differentiated from Ruellia brevifolia by the straight corolla tube (vs. ventricose).

\section{Ruellia brevifolia (Pohl) C. Ezcurra, Darwiniana} 29: 278.1989.

Figs. 2i; 3i-k

Shrubs, erect, up to $1.5 \mathrm{~m}$ tall. Branches quadrangular, never dilated in the internodes, glabrescent with trichomes only on the nodes, cystoliths absent. Leaves, petiole $1.5-3 \mathrm{~cm}$ long, blade narrowly elliptical to lanceolate, 6-16 $\times$ $1.5-5 \mathrm{~cm}$, glabrescent on both surfaces, cystoliths present, apex acuminate, base attenuate, margin entire to crenulate, glabrous. Inflorescences cymose, with many flowers composing dichasia, pedunculate, axillary to terminal, alternate to opposite; inflorescence axes glabrescent; bracts and bracteoles narrowly elliptical to lanceolate, 1-1.4 mm long, glabrescent. Flowers, pedicel 2-15 mm long; calyx 5-lobed, lobes linear to lanceolate 10-11 mm, pubescent; corolla red externally, whitish internally on the unexpanded portion, tubular, ventricose, $3.5-4.2 \mathrm{~cm}$ long, tube 2.9-3.7 cm long, lobe 3-5 mm long; stamens 4, included, trichomes absent at the base, anthers dithecous, parallel, base sagittate; nectariferous disk present; ovary cylindrical, about $3 \mathrm{~mm}$ long, pubescent. Fruits clavate capsules, about $1.5 \mathrm{~cm}$ long. Seeds 8, suborbicular.

Selected material: Foz do Iguaçu, fl., L.C. Pires. 753 (EVB); trilha das Bananeiras, 7.VII.2016, fl. and fr., J.K. Hammes et al. 145 (UNOP); cataratas, 22.V.2015, fl., M.G. Caxambu et al. 6439 (HCF); escola parque, 14.II.2013, fl., M.L. Toderke et al. 51 (UNOP); trilha do hidrante, 27.XI.2015, fl. and fr., J.K. Hammes et al. 81 (UNOP). Macuco, 16.XII.1992, fl., A.C. Cervi et al. 3916 (MBM); 7.VII.2016, fl., J.K. Hammes et al. 135 (UNOP). Poço Preto, 3.X.2006, fl., O.S. Ribas et al. 7401 (MBM); 21.IV.2007, fl., L.G. Temponi et al. 444 (UNOP); 28.VI.2007, fl. and fr., E. Barbosa \& O.S. Ribas 2206 (MBM); VIII.2009, fl., L.G. Temponi et al. 537 (UNOP); 11.X.2009, fl., L.G. Temponi et al. 659 (UNOP, MBM); 30.III.2011, fl., M. Lautert et al. 04 (UNOP); 24.III.2016, fl. and fr., J.K. Hammes et al. 99 (UNOP); trilha da represa, 21.V.2015, fl., M.G. Caxambu et al. 6340 (HCF); visitação, 7.VII.2016, fl., J.K. Hammes et al. 134 (UNOP); 7.VII.2016, fl., J.K. Hammes et al. 153 (UNOP).

Ruellia brevifolia has a tropical and subtropical distribution in South America, being found in Colombia, Ecuador, Peru, Brazil, Paraguay and Argentina (Ezcurra 1993). It can be found in the North, Central-West, Southeast and South, in areas of Cerrado and Ombrophilous Forest (BFG 2018). This species has not been evaluated for conservation status. However, in PARNA Iguaçu, this species was only found in SSF, in the area of Foz do Iguaçu. It blooms from October to August, with fruits in the months of March, June and July.

This species is recognized by its nonbilabiate, red and especially its ventricose corolla.

12. Ruellia erythropus (Nees) Lindau, Die Natürlichen Pflanzenfamilien 4(3b): 311. 1895.

Herbs, erect, up to $0.45 \mathrm{~m}$ tall. Branches subquadrangular to cylindrical, sometimes dilated in the internodes, glabrescent with a horizontal band of trichomes near the nodes, cystoliths inconspicuous. Leaves, petiole up to $0.5 \mathrm{~cm}$ long, blade elliptical to rhombic, 3.5-4.6 $\times 1.7-2.4 \mathrm{~cm}$, glabrescent on both surfaces and pubescent along the veins, cystoliths present, apex acuminate, base attenuate, decurrent along the petiole, margin slightly sinuous, pubescent. Inflorescences spicate with leaf-like bracts, axillary, opposite; inflorescence axes pubescent; bracts and bracteoles elliptical to ovate, $1.1-2 \mathrm{~cm}$ long, pubescent. Flowers, calyx 5-lobed, lobes with four segments joined in two smaller pairs, 2-4 mm long and a larger one $7 \mathrm{~mm}$ long, lobes lanceolate, pubescent; corolla lilac to blue externally, without differentiation along the expanded and unexpanded portion, infundibuliform, straight, $2.8-3 \mathrm{~cm}$ long, tube $1-1.5 \mathrm{~cm}$ long, lobes 3-4 mm long; stamens 4, included, trichomes present at the base, anthers dithecous, thecae inserted at the same heights in the connective, divergent only at the base, base sagittate; nectariferous disk present; ovary pyriform, about $3 \mathrm{~mm}$ long, glabrescent. Fruits ovate capsules, about $8 \mathrm{~mm}$ long. Seeds 4, suborbicular.

Examined material: Foz do Iguaçu, próximo às margens da BR-469, 14.VIII.2015, fl. and fr., M.G. Caxambu 6768 (HCF, UNOP).

This species occurs in Mexico, Bolivia, Paraguay, Brazil and Argentina (Ezcurra 1993). In Brazil, it can be found in the Central-West, Southeast and South, in areas of Cerrado and Ombrophilous Forest (BFG 2018). According to CNCFlora (2016), this species is widely distributed in Brazil and can be found in forest areas, being considered of little concern. However, in PARNA Iguaçu it was found only in SSF, in the area of Foz 
do Iguaçu, with flowers and fruits in August.

Ruellia erythropus is recognized by its spicate inflorescences, with leafy bracts and purple corolla, and the capsule which placenta and the retinaculum are released from the capsule wall (Ezcurra 1993).

13. Stenandrium mandioccanum $\mathrm{Nees}$, A Natural System of Botany 444. 1836.

Herbs, subscandent, stem up $1.6 \mathrm{~m}$ tall. Branches, subquandrangular, never dilated in the internodes, pubescent, cystoliths absent. Leaves, petiole 1-2 $\mathrm{cm}$ long, blade elliptical to ovate, $2.5-6 \times 1.5-3.5 \mathrm{~cm}$, glabrescent on both surfaces and pubescent along the veins, cystoliths absent, apex rounded, base attenuate, margin entire to slightly sinuous, pubescent. Inflorescences spicate, pedunculate, terminal; inflorescence axes pubescent; bracts and bracteoles elliptical to obovate, $10-11 \mathrm{~mm}$ long pubescent. Flowers, calyx 5-lobed, lobes lanceolate, 4-5 mm long, pubescent; corolla lilac to bright pink, without differentiation along the throat, glabrous, infundibuliform, straight, 8-9 $\mathrm{mm}$ long, tube 3-4 $\mathrm{mm}$ long, lobes 3-4 mm long; stamens 4, included, trichomes present along the base, anthers monothecous, base not sagittate; nectariferous disk present; ovaries cylindrical, about $1 \mathrm{~mm}$ long, glabrous. Fruits obovoid capsules, $0.7-0.8 \mathrm{~cm}$ long. Seeds 4, ellipsoid.

Examined material: Foz do Iguaçu, Bananeiras, 12.X.2009, fl. and fr., L.G. Temponi et al. 672 (UNOP); cataratas, 8.XII.1969, fl., G. Hatschbach 23176 (MBM); margens da BR-469, 18.VI.2015, fl., M.G. Caxambu et al. 6766 (HCF); Parque Nacional, 18.II.1963, fl. and fr., G. Hatschbach 9910 (MBM); 22.VIII.1980, fl., E. Barbosa \& E.F. Costa 980 (MBM); 21.XI.1989, fl., A.C. Cervi et al. 3029 (MBM). Poço Preto, 12.X.1986, fl. and fr., G. Hatschbach 50632 (MBM); 3.X.2006, fl., O.S. Ribas et al. 7400 (MBM).

It occurs in Ecuador, Peru, Brazil, Paraguay and Argentina, sporadically in Bolivia and the Andes (Wasshausen \& Wood 2004). In Brazil, on the other hand, it can be found in the Southeast and South, only in Ombrophilous Forest (BFG 2018). This species was not evaluated for conservation status. However, in PARNA Iguaçu, this species was found only in SSF, in the area of Foz do Iguaçu. Stenandrium mandioccanum blooms from August to February and in June and was found with fruits in February and October.

This species is recognized by its obovate bracts and infundibuliform corolla, up to 1 $\mathrm{cm}$ long, lilac to pink in coloration, without differentiation in the corolla and glabrous.

In addition to these 13 species, the occurrence of three exotic species of the Atlantic Forest was verified: Odontonema tubaeforme (Bertol.) Kuntze, a species originating in Central America, Thunbergia grandiflora var. laurifolia (Lindl.) Benoist, originating in India and Sanchezia oblonga Ruiz \& Páv., native of Brazil, but with natural occurrence only in Acre (Lorenzi 2013). These were not included in the taxonomic treatment, since their records are exclusively in anthropized areas in PARNA Iguaçu, such as near the Park School and Cataratas Hotel, and the family is widely known for its ornamental potential.

This study added 12 new species of Acanthaceae to PARNA Iguaçu. Of the 13 species inventoried, eight are new records for Semideciduous Seasonal Forest (Hygrophila costata, Justicia comata, Justicia ramulosa, Ruellia brevifolia, Ruellia erythropus, Stenandrium mandioccanum, Pachystachys dubiosa and Poikilacanthus glandulosus). Of these species, only Justicia ramulosa had been registered for the Deciduous Seasonal Forest, the others were registered in Araucaria Forest (BFG 2018).

Among the species found, two are threatened with extinction, one is considered vulnerable (Justicia ramulosa) and Pachystachys dubiosa is categorized as in endangered. For the latter, there is only one record in the state of Paraná within PARNA Iguaçu, in the areas of Céu Azul and Foz do Iguaçu, reinforcing the need to preserve the Park for the conservation of these species in the study area and in the state of Paraná.

PARNA Iguaçu presents a high richness of native species of Acanthaceae when compared to other studies such as those of Kameyama (2014), which identified 52 species, and BFG 2018), which identified 54 species for the entire state of Paraná. Marchioretto et al. (2015), in turn, found 34 species for the entire state of Rio Grande do Sul.

In a survey conducted throughout southern Brazil, Argentina, Chile, Paraguay, and Uruguay, 124 species were found (Zuloaga \& Belgrano 2015), of which the Acanthaceae species in PARNA Iguaçu corresponds to almost $10 \%$, despite being a much smaller area.

In more local studies, the number of species is even lower as reported by Braz et al. 2002 with six species for a small reserve in Minas Gerais. While in the flora of Ilha do Cardoso, 13 species were found (Kameyama 2015) and in Serra do 
Cipó, 13 species were also found (Kameyama 1995).

In addition, some of the species found are considered endangered or restricted in occurrence, which demonstrates the importance of conservation of this area for the maintenance of biodiversity in interior plant formations and the need for studies with non-arboreal taxa.

\section{Acknowledgments}

To CAPES, for the master's scholarship granted to the first author; to the Universidade Estadual do Oeste do Paraná, for the infrastructure made available; and to the curators of the herbaria EVB, HCF, MBM. We also thank the illustrator Thaís Regina Marcon.

\section{References}

Alvares CA, Stape JL, Sentelhas PC, Gonçalves JLM \& Sparovek G (2013) Köppen's climate classification map for Brazil. Meteorologische Zeitschrift 22: 711-728.

Barroso GM (1991) Sistemática de angiospermas do Brasil. UFV, Imprensa Universitária, Viçosa. 377p.

BFG - The Brazil Flora Group (2018) Brazilian Flora 2020: innovation and collaboration to meet Target 1 of the Global Strategy for Plant Conservation (GSPC). Rodriguésia 69: 1513-1527.

Bridson D \& Forman L (2010) The herbarium handbook. $3^{\text {rd }}$ ed. The Royal Botanic Garden, Kew. 214p.

CNCFlora - Centro Nacional de Conservação da Flora (2016) Lista vermelha da flora brasileira. Available at $<$ http://cncflora.jbrj.gov.br/portal $>$. Access on 20 August 2016.

Ezcurra C (1993) Systematics of Ruellia (Acanthaceae) in Southern South America. Annals of the Missouri Botanical Garden 80: 787-845.

Ezcurra C (1999) Acanthaceae Juss. Aportes Botánicos De Salta - Ser. Flora. 6: 1-45.

Ezcurra C (2002) El género Justicia (Acanthaceae) en Sudamérica Austral. Annals of the Missouri Botanical Garden 89: 225-280.

Ezcurra (2019) Acanthaceae. In: Zuloaga F \& Belgrano M (eds.) Iboda Conicet, Buenos Aires. Flora vascular de la República Argentina 20: 1-76.

Filgueiras TS, Brochado AL, Nogueira PE \& Guala II GF (1994) Caminhamento-um método expedito para levantamentos florísticos qualitativos. Cadernos de Geociências 2: 39-43.

IAPAR - Instituto Agronômico do Paraná (2010) Cartas climáticas do Paraná. Available at <http://www. iapar.br/modules/conteudo/conteudo.php?conteudo $=863>$. Access on 23 August 2015 .

ICMBio- Instituto Chico Mendes de Conservação da Biodiversidade (2018) Plano de Manejo do Parque
Nacional do Iguaçu. Available at <https://www. icmbio.gov.br/portal/images/stories/plano-demanejo/plano_de_manejo_do_parna_do_iguacu fevereiro 2018.pdf $>$. Access on 15 January 2019

IPNI - The International Plant Names Index (2016) Disponível em <http://www.ipni.org $>$. Access on 10 October 2016.

Judd WS (2009) Sistemática vegetal: um enfoque filogenético. Artmed, Porto Alegre. 625p.

Kameyama C (1995) Flora da Serra do Cipó, Minas Gerais: Acanthaceae. Boletim de Botânica da Universidade de São Paulo 14: 181-206.

Kameyama C (2006) Flora da Reserva Ducke, Amazonas, Brasil: Acanthaceae. Rodriguésia 57: 149-154.

Kameyama C (2014) Acanthaceae. In: Kaehler M, Goldernberg R, Evangelista PHL, Ribas OS, Vieira AOS \& Hatschbach GG (eds.) Plantas vasculares do Paraná. Universidade Federal do Paraná, Curitiba. Pp. 63-64.

Kameyama C (2015) Acanthaceae. In: Melo MMRF, Barros F, Chiea SAC, Kirizawa M, JungMendançolli SL \& Wanderley MGL (eds.) Flora fanerogâmica da Ilha do Cardoso. Instituto de Botânica, São Paulo. 202p.

Lorenzi H (2013) Plantas para jardim no Brasil: herbáceas, arbustivas e trepadeiras. Instituto Plantarum, Nova Odessa. 1120p.

Marchioretto MS, Silva VRSP \& Parode MF (2015) A família Acanthaceae Juss. no Rio Grande do Sul. Instituto Anchietano de Pesquisas 68: 7-82.

McDade LA, Masta SE, Moody ML \& Waters E (2000) Relationships among Acanthaceae: evidence from Two Genomes. Systematic Botany 25: 106-121.

McDade LA, Daniel TF \& Kiel CA (2008) Toward a comprehensive understanding of phylogenetic relationships among lineages of Acanthaceae s.l. (Lamiales). American Journal of Botany 95: 11361152 .

Profice SR (2010) Novas combinações para espécies brasileiras de Acanthaceae. Rodriguésia 61: S85-S88.

Profice SR \& Andreata RHP (2011) Revisão Taxonômica de Aphelandra R.Br. (Acanthaceae) de Corola Curto-Bilabiada. Botânica 62: 7-70.

Profice SR (2013) Acanthaceae Juss. da reserva Rio Das Pedras, Mangaratiba, RJ, Brasil. Botânica 64: 65-83.

Radford AE, Dickison WC, Massey JR \& Bell CR (1974) Vascular plant systematics. Harper \& Row, London. 201p.

Rizzini CT (1952)Acanthacearum delectus Brasiliensium. Dusenia 3: 181-196.

Silva MG (2011) Estudo taxonômico da subtribo Ruelliinae Nees (Acanthaceae) no estado do Paraná, Brasil. Dissertação de Mestrado. Universidade Federal do Paraná, Curitiba. 66p.

Stevens PF (2012)Angiosperm Phylogeny Website. Version 12. Available at $<$ http://www.mobot.org/MOBOT/ research/APweb/>. Access on 22 March 2019. 
Thiers B [continuously updated] Index Herbariorum: a global directory of public herbaria and associated staff. New York Botanical Garden's Virtual Herbarium. Available at $<$ http://sweetgum.nybg.org/ science/ih/>. Access on 20 august 2016.

Toderke ML (2015) Levantamento florístico e distribuição das espécies de Rubiaceae no Parque Nacional do Iguaçu, Paraná, Brasil. Dissertação de Mestrado, Universidade Estadual do Oeste do Paraná, Cascavel. 116p.

Tropicos.org (2019) Missouri Botanical Garden. Available at $<$ http://www.tropicos.org/Name/103771>. Access on 04 June 2019

Walter BMT \& Guarino ESG (2006) Comparação do método de parcelas com o "levantamento rápido" para amostragem da vegetação arbórea do Cerrado sentido restrito. Acta Botânica Brasilica 20: 285-297.
Wasshausen DC \& Wood JRI (2004) Acanthaceae of Bolivia. Contributions from the United States National Herbarium 49: 1-152.

Wasshausen DC (1995). Acanthaceae. In: Berry PE, Holst BK \& Yatskievych K (eds.) The Missouri Botanical Garden. Vol. 2. Flora of the Venezuelan Guayana, St Louis. Pp. 335-373.

Weberling F (1981) Morphology of flowers and inflorenscences. Combridge University, Cambridge. $201 \mathrm{p}$.

Witztum A \& Schulgasser K (1995) The mechanics of seed expulsion in Acanthaceae. Journal of Theoretical Biology 176: 534-542.

Zuloaga FO \& Belgrano MJ (2015) The catalogue of vascular plants of the Southern Cone and the Flora of Argentina: their contribution to the World Flora. Rodriguésia 66: 989-1024. 